\title{
Evaluation of Antidiabetic and Antioxidative Efficacy of Strychnos Potatorum (Nirmali) Seeds Extract in High Fat Diet Fed- Low Dose Streptozotocin Induced Experimental Type 2 Diabetes in Rats
}

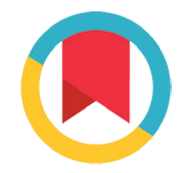

CrossMark

\author{
Chandiran Sharmila, Sorimuthu Pillai Subramanian*
}

\section{ABSTRACT:}

Objective: Type 2 diabetes mellitus is a multifactorial, multisystemic chronic endocrine disorder characterized by insufficient insulin secretion in association with insulin resistance. Strychnos potatorum Linn. seeds have been used in the traditional system of medicine for the treatment of various non communicable diseases including diabetes mellitus. In the present study, we have evaluated the antidiabetic and antioxidant properties of Strychnos potatorum seeds extract in type 2 diabetic rats. Chronic hyperglycemia promotes autooxidation of glucose to generate excessive free radicals which results in the development of both macro- and microvascular complications.

Design: S. potatorum seeds were delipidated and the ethanolic extract was subjected to qualitative phytochemical screening. The total phenolic, flavonoid, carbohydrate and protein contents were estimated. High fat fed and -Low dose streptozotocin induced type 2 diabetic rats were orally treated with S. potatorum seeds extract $(500 \mathrm{mg} / \mathrm{kg}$ b.w./ rat/day) for 30 days. The levels of important biochemical indices and oxidative stress markers such as lipid peroxides, hydroperoxides and protein carbonyls were determined in plasma and vital tissues. The levels of both enzymatic and non enzymatic antioxidants were also evaluated.

Results: Diabetic rats showed significantly increased levels of fasting blood glucose and glycosylated hemoglobulin. The oxidative stress markers were significantly increased and levels of both enzymatic and non enzymatic antioxidants were declined. Oral treatment of $S$. potatorum seeds extract results in the maintenance of normoglycemia by decreasing the levels of oxidative stress markers and improved the status of antioxidants in diabetic rats.

Conclusions: S. potatorum seeds possess significant antidiabetic properties which may partially responsible for its antioxidant properties.

Key Words: Strychnos potatorum, oxidative stress, antidiabetic property, antioxidant activity.

${ }^{*}$ Correspondence to:

Dr.S.Subramanian, Professor, Department of Biochemistry, University of Madras, Guindy Campus, Chennai- 600025 , subbus2020@yahoo.co.in

Cite This Article: Subramanian, C.S.S.P. 2020. Evaluation of Antidiabetic and Antioxidative Efficacy of Strychnos Potatorum (Nirmali) Seeds Extract in High Fat Diet Fed- Low Dose Streptozotocin Induced Experimental Type 2 Diabetes in Rats. Diabesity 6(1): 1-8. DOl: $10.15562 /$ diabesity.2020.63

\section{INTRODUCTION}

Diabetes mellitus (DM) is a complex and chronic metabolic disorder with an incidence varying between 6 to $8 \%$ Worldwide. It is characterized by a persistent elevation in both fasting and postprandial blood glucose levels. It arises due to the absolute lack of insulin secretion (T1DM) or its insufficiency coupled with the development of peripheral resistance to insulin action (T2DM). ${ }^{1}$ The alarming increase in the incidence of T2DM arises due to obesity, lack of exercise and sedentary lifestyle in addition to genetic predisposition. The diabetic individuals are prone to have a two to fivefold increase in the incidence of both microvascular and macrovascular complications when compared to the non-diabetic population. Experimental and clinical studies evidenced the role of hyperglycemia-induced oxidative stress in the etiology of secondary complications of DM. ${ }^{2}$ Oxidative stress arises due to an imbalance between the generation of free radicals and the availability of antioxidants in favour of the former and is capable of inflicting injury to membrane lipids, proteins and nucleic acids. ${ }^{3}$ Most of the currently available drugs for the treatment of diabetes possess antioxidant properties next to their antidiabetic action. ${ }^{4}$ In spite of great advancements in the field of science and technology in the early diagnosis and prognosis, the maintenance of normoglycemia in diabetic patients remains a task for the clinicians. Hence the search for novel drugs capable of controlling the oxidative stress and hyperglycemia effectively at a low dose continues.

Strychnos potatorum Linn, commonly known as Nirmali, belongs to the family Loganiaceae. The plant is extensively referred to as a "clearing nut tree" owing to its seeds which have been traditionally used for the purification of water. ${ }^{5}$ It is a moderate sized glabrous deciduous tree widely distributed in the forests of South India and West Bengal. It is also found in tropical African countries, Sri Lanka and 
Burma. In folklore medicine, the seeds were used for the treatment of diabetes and its secondary complications. ${ }^{6}$ However, the seeds lack scientific appraisal for its toxicological and pharmacological properties. The present study is aimed to evaluate the antidiabetic as well as antioxidative efficacy Nirmali seeds in the high fat diet fed- low dose streptozotocin induced experimental type 2 diabetes in rats.

\section{MATERIALS AND METHODS:}

\section{Chemicals and drugs}

Streptozotocin (STZ) was procured from Sigma Chemicals, St Louis, USA. Plasma insulin and C-peptide were purchased from Linco Research, Inc., USA. AGEs were obtained from Abcam, Cambridge, UK. All other chemicals such as Metformin, Cholesterol and other reagents used in the present study were of analytical grade obtained from SRL chemicals, Bombay, India.

\section{Plant Material}

Fresh and matured Strychnos potatorum seeds were procured from an authorized traditional medical shop in Mylapore, Chennai and authenticated by a qualified a taxonomist in the Centre for Advanced Studies in Botany, University of Madras, Guindy Campus, Chennai and the voucher specimen was deposited in the departmental herbarium (No.BC-CS-SP-1). The seeds were shadow dried and coarsely powdered to obtain a 40 mesh range and were stored in an airtight brown container at $5^{\circ} \mathrm{C}$ until further use. The powdered seeds were delipidated with petroleum ether $\left(60-80^{\circ} \mathrm{C}\right)$ overnight and the extract was filtered. Soxhalation was performed with $95 \%$ ethanol to extract the phytoingredients from the seeds. The extract was separated by filtration and concentrated on a rotary evaporator at $40-50^{\circ} \mathrm{C}$ under reduced pressure and the brownish yellow coloured semi-solid mass obtained was dried under vacuum. The yield was around $18.5 \%$ of dry weight.

\section{Preliminary phytochemicals screening}

The ethanolic extract of the S.potatorum seeds was subjected to phytochemical screening for the qualitative analysis of various phytoconstituents such as Alkaloids, Sterols, Flavonoids, Glycosides, Saponins, Tannins, Phytosterols, Triterpenoids, Anthraquinones and Phenols. ${ }^{7}$

\section{Determination of Total phenolic, flavonoids, carbohydrate and protein contents}

The total phenolic ${ }^{8}$ and flavonoids ${ }^{9}$ contents of S.potatorum seeds were estimated using gallic acid and quercetin as reference standards respectively. The total carbohydrate ${ }^{10}$ and protein ${ }^{11}$ contents in the seeds extract were estimated by the established methods.

\section{Acute toxicity and dosage fixation studies}

Acute toxicity and dosage fixation studies were performed as per the OECD guidelines (423) for the determination of acute toxicity of chemicals in normal rats. Based on the reports available in the literature, the dosage fixation studies were carried out by administering graded doses of $S$. potatorum seeds extract at a concentration of 100,200,400,500 and $600 \mathrm{mg} / \mathrm{kg}$ b.w./rat/day for 30 days to determine the dose-dependent hypoglycemic effect in experimental diabetic rats.

\section{Experimental animals}

Six to eight weeks old male Wistar rats weighing about 160-180 g, procured from Tamilnadu Veterinary and Animal Sciences University, Chennai, India, were housed in clean, sterile, polypropylene cages $((38 \times 23 \times 15 \mathrm{~cm})$ under standard vivarium conditions. The animals were allowed free access to standard rat chow diet (Hindustan Lever Ltd., India) or high fat diet as the case may be and water ad libitum. The composition of the standard rat diet includes $5 \%$ fat, $21 \%$ protein, $55 \%$ nitrogen-free extract and $4 \%$ fiber (w/w) with adequate minerals and vitamins for the animals. The animals were acclimatized to the laboratory conditions for 2 weeks before the commencement of experiments. The animal experiments were performed according to the regulations lay down by the Committee for the Purpose of Control and Supervision on Experiments on Animals (CPCSEA) as well as Institutional Animal Ethics Committee Guidelines.

\section{High-fat diet fed and low-dose STZ-induced Type 2 diabetes}

The High Fat Diet (HFD) was prepared indigenously by using normal pellet diet, raw cholesterol, a mixture of Vanaspati ghee and pure coconut oil (2:1). Briefly, the normal rat pellet diet was powdered by grinding and mixed with 2.5\% cholesterol and a mixture of Vanaspati ghee and coconut oil (5\%). The mixture was made into pellet form and orally fed to rats to induce metabolic syndrome. ${ }^{12}$ The rats were divided into two dietary regimens by feeding either normal or HFD for the initial period of 2 weeks. After 2 weeks of dietary management to develop insulin resistance, the groups of rats fed with HFD were intraperitoneally injected with a freshly prepared low dose of STZ (35 mg/kg b.w) dissolved in $0.1 \mathrm{M}$ ice-cold citrate buffer, $\mathrm{pH} 4.5{ }^{13}$ After 3 days of injection with STZ, 
the experimental rats were screened for fasting blood glucose levels. The experimental rats which show the fasting blood glucose above $250 \mathrm{mg} / \mathrm{dl}$ were considered as diabetic and chosen for further experimental studies. Metformin was used as a reference drug to compare the efficacy of the seeds extract. $^{4}$

\section{Experimental Protocol}

The rats were divided into four groups each comprising six rats.

Group 1: Control rats

Group 2: Diabetic rats (HFD fed-low dose STZ; $35 \mathrm{mg} / \mathrm{kg}$ b.w.)

Group 3: Diabetic rats treated with S. potatorum seeds extract ( $500 \mathrm{mg} / \mathrm{kg}$ b.w.)

Group 4: Diabetic rats treated with metformin (50 mg/kg b.w.).

During the experimental period, body weight, blood glucose, food and water consumption and physical examinations were determined at regular intervals. At the end of the treatment period, the rats were fasted overnight, anesthetized and sacrificed by cervical decapitation. The blood was collected with or without anticoagulants for plasma or serum separation, respectively. The liver pancreatic tissues were selectively dissected out and washed in ice-cold saline and used for further experimental studies.

\section{Assay of basic biochemical parameters}

The levels of fasting blood glucose, glycosylated hemoglobin, plasma protein, blood urea, uric acid and serum creatinine were determined by standardized methods. Plasma insulin and C-peptide were assayed using ELISA kit for rats (Linco Research, Inc., USA). The presence of urine sugar was detected using urine strips (Diastix).

\section{In vivo antioxidant assay \\ Determination of Antioxidant Status}

The levels of lipid peroxides, hydroperoxides and protein carbonyls were determined in plasma and tissue homogenate. ${ }^{14-16}$ The activities of enzymatic antioxidants such as SOD, ${ }^{17}$ Catalase, ${ }^{18} \mathrm{GPx},{ }^{19}$ $\mathrm{GST}^{20}$ were assayed in the pancreatic, hepatic and renal tissue homogenate of control and experimental groups of rats. The levels of non-enzymatic antioxidants, vitamin $\mathrm{C},{ }^{21}$ vitamin $\mathrm{E},{ }^{22}$ ceruloplasmin ${ }^{23}$ and $\mathrm{GSH}^{24}$ were determined.

\section{Statistical analysis}

The results were expressed as mean \pm SEM of six rats in each group, and the statistical significance was evaluated by one-way Analysis of Variance (ANOVA) using the SPSS (version 16) program followed by the least significant difference (LSD). Values were considered statistically significant when $\mathrm{p}<0.05$.

\section{RESULTS}

The yield after ethanolic extraction of the seeds was around $18.5 \% \mathrm{w} / \mathrm{w}$. The qualitative phytochemicals analysis revealed the presence of pharmacologically active phytochemicals namely alkaloids, sterols, flavonoids, tannins, glycosides, triterpenoids, saponins and phenolic compounds in the delipidated seeds extract. The total phenolic, flavonoids, carbohydrate and protein content in the seeds extract were found to be $16.72 \pm 1.13 \mu \mathrm{g}$ gallic acid equivalents, $10.05 \pm 0.16 \mu \mathrm{g}$ quercetin equivalents, $4.19 \pm$ $0.28 \mathrm{mg} / \mathrm{g}$ and $2.26 \pm 0.32 \mathrm{mg} / \mathrm{g}$ of the seeds extract respectively.

The effect of oral administration of $S$. potatorum seeds extract at a concentration of $500 \mathrm{mg} / \mathrm{kg} / \mathrm{bw} /$ rat/day for 30 days on the levels of fasting blood glucose, hemoglobulin, glycosylated hemoglobulin (HbAlc) and plasma insulin in experimental type 2 diabetic rats is presented in Table 1 . In the diabetic group of rats, the levels of fasting blood glucose and $\mathrm{HbAlc}$ were significantly increased with a concomitant decrease in the levels of plasma insulin and hemoglobin. Treatment with seeds extract as well as metformin brought the altered levels of the above biochemical indices to physiological values. The urine sugar which was present in the diabetic group

Table 1 Levels of blood glucose, hemoglobin, glycosylated hemoglobin (HbA1c), plasma insulin and urine sugar in control and experimental groups of rats.

\begin{tabular}{|c|c|c|c|c|c|}
\hline Groups & Blood glucose & Hemoglobin & HbA1c & Insulin & Urine sugar \\
\hline Control & $92.00 \pm 3.20$ & $13.00 \pm 0.23$ & $7.64 \pm 0.35$ & $15.50 \pm 0.43$ & Nil \\
\hline Diabetic control & $256.00 \pm 9.500^{a^{*}}$ & $8.50 \pm 0.38^{a^{*}}$ & $14.80 \pm 0.40^{\mathrm{a}^{*}}$ & $10.50 \pm 0.21^{\mathrm{a}^{*}}$ & +++ \\
\hline Diabetic + S.potatorum & $130.50 \pm 3.30^{a^{*} b^{*} c}$ & $11.00 \pm 0.21^{\mathrm{a} @ \mathrm{~b}^{*} \mathrm{c}}$ & $7.60 \pm 0.29^{\mathrm{a}^{\sharp b^{*}} \mathrm{c}}$ & $12.20 \pm 0.30^{a^{a^{*} b^{*} c}}$ & Nil \\
\hline Diabetic + Metformin & $119.00 \pm 3.40^{\mathrm{a}^{*} \mathrm{~b}^{*}}$ & $12.60 \pm 0.46^{\mathrm{a}^{\sharp b^{*}}}$ & $7.30 \pm 0.21^{\mathrm{a}^{*} \mathrm{~b}^{*}}$ & $12.80 \pm 0.41^{\mathrm{a}^{*} \mathrm{~b}^{*}}$ & $\mathrm{Nil}$ \\
\hline
\end{tabular}

Units: $\mathrm{mg} / \mathrm{dl}$ for blood glucose, $\mathrm{g} / \mathrm{dl}$ for hemoglobin, \% hemoglobin for $\mathrm{HbAlc}, \mu \mathrm{U} / \mathrm{ml}$ for plasma insulin, pmol/ml for plasma C-peptide, +++ indicates more than $2 \%$ sugar.

Results are expressed as mean \pm S.E.M [n=6]. One-way ANOVA followed by post hoc test LSD. The results were compared with a Control rats, ${ }^{b} D i a b e t i c$ rats, cDiabetic rats treated with metformin. Values are statistically significant at ${ }^{\circledR} \mathrm{P}<0.05 ;{ }^{*} \mathrm{P}<0.01 ;{ }^{*} \mathrm{P}<0.001$. 
Table 2 Effect of S.potatorum seed extract on the levels of plasma protein, blood urea, serum uric acid and serum creatinine in control and experimental groups of rats.

\begin{tabular}{|c|c|c|c|c|}
\hline Groups & Protein & Urea & Uric acid & Creatinine \\
\hline Control & $9.00 \pm 0.10$ & $25.08 \pm 0.56$ & $2.40 \pm 0.10$ & $0.43 \pm 0.02$ \\
\hline Diabetic control & $6.00 \pm 0.08^{\mathrm{a}^{*}}$ & $47.80 \pm 0.80^{\mathrm{a}^{*}}$ & $6.33 \pm 0.23^{\mathrm{a}^{*}}$ & $1.18 \pm 0.02^{\mathrm{a}^{*}}$ \\
\hline Diabetic + S.potatorum & $7.56 \pm 0.13^{a b^{*} c}$ & $26.10 \pm 0.55^{a^{*} \mathrm{c}}$ & $2.70 \pm 0.12^{a @ b^{*} c}$ & $0.56 \pm 0.02^{a @ b * c}$ \\
\hline Diabetic + Metformin & $8.20 \pm 0.14^{a^{*}}$ & $25.00 \pm 0.53^{a^{*}}$ & $2.50 \pm 0.10^{a^{*}}$ & $0.53 \pm 0.02^{\mathrm{a}^{\mathrm{a} \mathrm{b}^{*}}}$ \\
\hline
\end{tabular}

Units: $\mathrm{g} / \mathrm{dl}$ for plasma protein, $\mathrm{mg} / \mathrm{dl}$ for blood urea, serum uric acid and serum creatinine.

Results are expressed as mean \pm S.E.M [n=6]. One-way ANOVA followed by post hoc test LSD. The results were compared with ${ }^{\mathrm{a} C o n t r o l ~ r a t s, ~}{ }^{\mathrm{b}} \mathrm{Diabetic}$ rats,

cDiabetic rats treated with metformin. Values are statistically significant at ${ }^{\circledR} \mathrm{P}<0.05 ;{ }^{*} \mathrm{P}<0.01 ;{ }^{*} \mathrm{P}<0.001$.

Table 3 The levels of lipid peroxides, hydroperoxides and protein carbonyls in plasma of control and experimental groups of rats after 30 days of experimental period.

\begin{tabular}{|c|c|c|c|}
\hline Groups & Lipid peroxides & Hydroperoxides & Protein carbonyls \\
\hline Control & $3.60 \pm 0.22$ & $9.9 \pm 0.50$ & $6.50 \pm 0.33$ \\
\hline Diabetic control & $10.2 \pm 0.33^{a^{*}}$ & $27.30 \pm 2.15^{\mathrm{a}^{*}}$ & $26.53 \pm 2.00 \mathrm{a}^{*}$ \\
\hline Diabetic + S.potatorum & $4.45 \pm 0.28^{\mathrm{ab}^{*} \mathrm{c}}$ & $17.80 \pm 1.50^{\mathrm{a} \# b^{* c}}$ & $14.44 \pm 0.83^{\mathrm{a}^{*} \mathrm{~b}^{*} c}$ \\
\hline Diabetic + metformin & $4.61 \pm 0.25^{\mathrm{a} \# \mathrm{~b}^{*}}$ & $15.61 \pm 1.12^{\mathrm{a}^{*} \mathrm{~b} \#}$ & $14.00 \pm 0.91^{\mathrm{a} \# \mathrm{~b}^{*}}$ \\
\hline
\end{tabular}

Units are expressed as: $\mathrm{nM} / \mathrm{ml}$ for lipid peroxides; $10^{-5} \mathrm{mM} / \mathrm{dl}$ for hydroperoxides; $\mathrm{nM} / \mathrm{mg}$ of protein for protein carbonyls.

Results are expressed as mean \pm S.E.M [n=6]. One-way ANOVA followed by post hoc test LSD. The results were compared with ${ }^{\mathrm{a} C o n t r o l ~ r a t s, ~}{ }^{\mathrm{b}} \mathrm{Diabetic}$ rats,

'Diabetic rats treated with metformin. Values are statistically significant at ${ }^{\circledR} \mathrm{P}<0.05 ;{ }^{*} \mathrm{P}<0.01 ;{ }^{*} \mathrm{P}<0.001$.

Table 4 Effects of S.potatorum seeds extract on the levels of lipid peroxides, hydroperoxides, and protein carbonyls in pancreatic tissues of experimental groups of rats.

\begin{tabular}{|c|c|c|c|}
\hline Groups & Lipid peroxides & Hydroperoxides & Protein carbonyls \\
\hline Control & $37.33 \pm 2.40$ & $14.10 \pm 0.88$ & $5.18 \pm 0.25$ \\
\hline Diabetic control & $65.21 \pm 4.33^{\mathrm{a}^{*}}$ & $32.04 \pm 1.71^{\mathrm{a}^{*}}$ & $20.10 \pm 1.13^{\mathrm{a}^{*}}$ \\
\hline Diabetic + S.potatorum & $40.00 \pm 2.40^{a^{*}{ }^{*} c}$ & $17.32 \pm 1.15^{\mathrm{ab}^{*} \mathrm{c}}$ & $11.21 \pm 0.58^{\mathrm{a}^{\mathrm{a}^{*} \mathrm{~b}^{*} \mathrm{c}}}$ \\
\hline Diabetic + Metformin & $38.30 \pm 3.00 \mathrm{a@b}^{\mathrm{b}^{*}}$ & $15.02 \pm 0.71^{\mathrm{ab}^{*}}$ & $10.88 \pm 0.62^{\mathrm{a}^{*} \mathrm{~b}^{*}}$ \\
\hline
\end{tabular}

Units are expressed as: $\mathrm{mM} / 100 \mathrm{~g}$ of wet tissue for lipid peroxides and hydroperoxides; $\mathrm{nM} / \mathrm{mg}$ of protein for protein carbonyls.

Results are expressed as mean \pm S.E.M [n=6]. One-way ANOVA followed by post hoc test LSD. The results were compared with ${ }^{a}$ Control rats, ${ }^{b}$ Diabetic rats, ${ }^{c}$ Diabetic rats treated with metformin. Values are statistically significant at ${ }^{\circledR} \mathrm{P}<0.05 ;{ }^{*} \mathrm{P}<0.01 ;{ }^{*} \mathrm{P}<0.001$.

Table 5 Effects of S.potatorum seeds extract on the levels of lipid peroxides, hydroperoxides, and protein carbonyls in hepatic tissues of control and experimental groups of rats.

\begin{tabular}{lccc}
\hline Groups & Lipid peroxides & Hydroperoxides & Protein carbonyls \\
\hline Control & $1.37 \pm 0.12$ & $47.42 \pm 4.09$ & $4.51 \pm 0.32$ \\
Diabetic control & $4.41 \pm 0.25^{\mathrm{a}^{*}}$ & $127.10 \pm 7.03^{\mathrm{a}^{*}}$ & $14.20 \pm 0.76^{\mathrm{a}^{*}}$ \\
Diabetic + S.potatorum & $2.36 \pm 0.17^{\mathrm{a}^{*} \mathrm{~b}^{*}}$ & $81.74 \pm 4.02^{\mathrm{a}^{*} \mathrm{~b}^{*}}$ & $7.15 \pm 0.29 \mathrm{a}^{*^{*} \mathrm{~b}^{*}}$ \\
Diabetic + Metformin & $2.88 \pm 0.21^{\mathrm{a}^{*} \mathrm{~b}^{*}}$ & $71.41 \pm 3.12^{\mathrm{a}^{*} \mathrm{~b}^{*}}$ & $7.53 \pm 0.32^{\mathrm{a}^{*} \mathrm{~b}^{*}}$ \\
\hline
\end{tabular}

Units are expressed as: $\mathrm{mM} / 100 \mathrm{~g}$ of wet tissue for lipid peroxides and hydroperoxides; $\mathrm{nM} / \mathrm{mg}$ of protein for protein carbonyls.

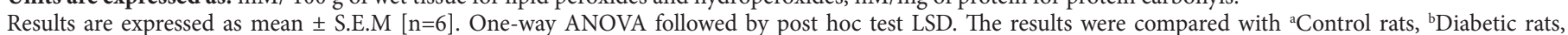
${ }^{c}$ Diabetic rats treated with metformin. Values are statistically significant at ${ }^{\circledR} \mathrm{P}<0.05 ;{ }^{*} \mathrm{P}<0.01 ;{ }^{\star} \mathrm{P}<0.001$.

of rats was absent in experimental groups of rats treated with seeds extract.

Table 2 depicts the levels of plasma protein, blood urea, serum uric acid and serum creatinine in control and experimental groups of rats. The decreased levels of plasma protein and increased levels of blood urea, serum uric acid and serum creatinine observed in the diabetic group of rats were reverted to near normalcy after treatment with seeds extract as well as metformin.

The significantly increased levels of lipid peroxides, hydroperoxides and protein carbonyls in plasma, pancreatic, hepatic and kidney tissues of HFD-STZ diabetic rats were declined near normal 
Table 6 Effect of S.potatorum seeds extract on the levels of lipid peroxides, hydroperoxides, and protein carbonyls in renal tissues of control and experimental groups of rats.

\begin{tabular}{lccc}
\hline Groups & Lipid peroxides & Hydroperoxides & Protein carbonyls \\
\hline Control & $1.05 \pm 0.073$ & $50.10 \pm 3.18$ & $3.75 \pm 0.30$ \\
Diabetic control & $3.40 \pm 0.20^{\mathrm{a}^{*}}$ & $85.50 \pm 3.80^{\mathrm{a}^{*}}$ & $17.47 \pm 0.89 \mathrm{a}^{*}$ \\
Diabetic + S.potatorum & $2.18 \pm 0.13^{\mathrm{a}^{*} \mathrm{~b}^{*} \mathrm{c}}$ & $59.28 \pm 3.58^{\mathrm{ab}^{*} \mathrm{c}}$ & $9.11 \pm 0.55^{\mathrm{a}^{*} \mathrm{~b}^{*}}$ \\
Diabetic + Metformin & $1.98 \pm 0.12^{\mathrm{a}^{*} \mathrm{~b}^{*}}$ & $60.11 \pm 4.40^{\mathrm{ab}^{*}}$ & $7.24 \pm 0.48^{\mathrm{a}^{*} \mathrm{~b}^{*} \mathrm{C}}$ \\
\hline
\end{tabular}

Units are expressed as: $\mathrm{mM} / 100 \mathrm{~g}$ of wet tissue for lipid peroxides and hydroperoxides; $\mathrm{nM} / \mathrm{mg}$ of protein for protein carbonyls.

Results are expressed as mean \pm S.E.M [n=6]. One-way ANOVA followed by post hoc test LSD. The results were compared with a Control rats, ${ }^{b} D i a b e t i c$ rats,

cDiabetic rats treated with metformin. Values are statistically significant at ${ }^{\circledR} \mathrm{P}<0.05 ;{ }^{*} \mathrm{P}<0.01 ;{ }^{*} \mathrm{P}<0.001$.

Table 7 Activities of Superoxide dismutase (SOD), Catalase, Glutathione peroxidase (GPx) and Glutathione-S-transferase (GST) in pancreatic tissues of control and experimental groups of rats.

\begin{tabular}{|c|c|c|c|c|}
\hline Groups & SOD & Catalase & GPx & GST \\
\hline Control & $5.57 \pm 0.32$ & $25.00 \pm 2.20$ & $6.81 \pm 0.31$ & $5.91 \pm 0.29$ \\
\hline Diabetic & $3.20 \pm 0.22^{\mathrm{a}^{*}}$ & $6.63 \pm 0.42^{a^{*}}$ & $3.10 \pm 0.24^{\mathrm{a}^{*}}$ & $2.00 \pm 0.311^{\mathrm{a}^{*}}$ \\
\hline Diabetic + S.potatorum & $4.44 \pm 0.20^{\mathrm{a}^{*} \mathrm{~b}^{*} \mathrm{c}}$ & $13.40 \pm 0.69^{a^{*} b \# c}$ & $5.59 \pm 0.34^{\mathrm{a} @ b^{*} c}$ & $4.50 \pm 0.24^{\mathrm{a}^{*} \mathrm{~b}^{*} \mathrm{c}}$ \\
\hline Diabetic + metformin & $4.91 \pm 0.33^{\mathrm{a}^{*} \mathrm{~b}^{*}}$ & $15.42 \pm 0.73^{\mathrm{a}^{\star \mathrm{b} \#}}$ & $6.13 \pm 0.34^{\mathrm{ab}^{*}}$ & $4.99 \pm 0.31^{\mathrm{a}^{*} \mathrm{~b}^{*}}$ \\
\hline
\end{tabular}

Activities of enzymes are expressed as: $50 \%$ of inhibition of epinephrine autoxidation $/ \mathrm{min}$ for SOD; $\mathrm{mM}$ of hydrogen peroxide decomposed/min/mg of protein for catalase; $\mathrm{mM}$ of glutathione oxidized $/ \mathrm{min} / \mathrm{mg}$ of protein for $\mathrm{GPx}$; U/min $/ \mathrm{mg}$ of protein for GST.

Results are expressed as mean \pm S.E.M [ $n=6]$. One-way ANOVA followed by post hoc test LSD. The results were compared with ${ }^{\mathrm{a} C o n t r o l ~ r a t s, ~}{ }^{b} \mathrm{Diabetic}$ rats,

'Diabetic rats treated with metformin. Values are statistically significant at ${ }^{\circledR} \mathrm{P}<0.05 ;{ }^{*} \mathrm{P}<0.01 ;{ }^{*} \mathrm{P}<0.001$.

Table 8 Activities of Superoxide dismutase (SOD), Catalase, Glutathione peroxidase (GPx), Glutathione-S-transferase (GST) and Glutathione reductase (GR) in hepatic tissues of control and experimental groups of rats.

\begin{tabular}{|c|c|c|c|c|c|}
\hline Groups & SOD & Catalase & GPx & GST & GR \\
\hline Control & $11.55 \pm 0.62$ & $80.10 \pm 3.11$ & $10.52 \pm 0.49$ & $8.09 \pm 0.46$ & $28.30 \pm 2.74$ \\
\hline Diabetic & $4.65 \pm 0.23^{\mathrm{a}^{*}}$ & $38.50 \pm 2.48^{\mathrm{a}^{*}}$ & $4.68 \pm 0.18^{\mathrm{a}^{*}}$ & $3.60 \pm 0.18^{\mathrm{a}^{*}}$ & $12.60 \pm 0.68^{\mathrm{a}^{*}}$ \\
\hline Diabetic + S.potatorum & $7.82 \pm 0.24^{\mathrm{a}^{*} \mathrm{~b}^{*} \mathrm{c}}$ & $67.10 \pm 2.44^{\mathrm{a}: \mathrm{b}^{*} \mathrm{c}}$ & $7.20 \pm 0.36^{\mathrm{a}^{*} \mathrm{~b}^{*} \mathrm{c}}$ & $6.43 \pm 0.28^{\mathrm{a}^{* \mathrm{~b}^{*} \mathrm{c}}}$ & $22.33 \pm 1.75^{\mathrm{a} \oplus \mathrm{b} \# \mathrm{c}}$ \\
\hline Diabetic + metformin & $7.20 \pm 0.27^{\mathrm{a}^{*} \mathrm{~b}^{*}}$ & $70.81 \pm 3.05^{\mathrm{a}^{*} \mathrm{~b}^{*}}$ & $8.00 \pm 0.23^{\mathrm{a}^{*} \mathrm{~b}^{*}}$ & $7.00 \pm 0.29 \mathrm{a}^{a * b^{*}}$ & $23.50 \pm 2.00 \mathrm{ab}^{*}$ \\
\hline
\end{tabular}

Activities of enzymes are expressed as: $50 \%$ of inhibition of epinephrine autoxidation/min for SOD; $\mathrm{mM}$ of hydrogen peroxide decomposed/min/mg of protein for catalase; $\mathrm{mM}$ of glutathione oxidized/min/mg of protein for GPx; U/min/mg of protein for GST; $\mu$ M of DTNB-GSH conjugate formed/min/mg of protein for GR.

Results are expressed as mean \pm S.E.M [n=6]. One-way ANOVA followed by post hoc test LSD. The results were compared with ${ }^{a}$ Control rats, ${ }^{b}$ Diabetic rats,

'Diabetic rats treated with metformin. Values are statistically significant at ${ }^{\circledR} \mathrm{P}<0.05 ;{ }^{*} \mathrm{P}<0.01 ;{ }^{*} \mathrm{P}<0.001$.

Table 9 Activities of Superoxide dismutase (SOD), Catalase, Glutathione peroxidase (GPx), Glutathione-S-transferase (GST) and Glutathione reductase (GR) in renal tissues of control and experimental groups of rats.

\begin{tabular}{|c|c|c|c|c|c|}
\hline Groups & SOD & Catalase & GPx & GST & GR \\
\hline Control & $17.20 \pm 0.93$ & $44.34 \pm 3.01$ & $8.0 \pm 0.24$ & $6.40 \pm 0.16$ & $33.11 \pm 2.00$ \\
\hline Diabetic & $8.23 \pm 0.51^{\mathrm{a}^{*}}$ & $17.10 \pm 1.11^{\mathrm{a}^{*}}$ & $3.66 \pm 0.21^{\mathrm{a}^{*}}$ & $2.42 \pm 0.16^{\mathrm{a}^{*}}$ & $11.40 \pm 0.72^{\mathrm{a}^{*}}$ \\
\hline Diabetic + S.potatorum & $14.08 \pm 0.58^{a @ b^{*} c}$ & $29.01 \pm 1.74^{\mathrm{a}^{*} \mathrm{~b}^{*} \mathrm{c}}$ & $6.50 \pm 0.23^{\mathrm{a}^{*} \mathrm{~b}^{*} \mathrm{c}}$ & $4.32 \pm 0.25^{\mathrm{a}^{*} \mathrm{~b}^{*} \mathrm{c}}$ & $26.51 \pm 1.78^{\mathrm{a} @ \mathrm{~b}^{*} \mathrm{c}}$ \\
\hline Diabetic + metformin & $13.39 \pm 0.45^{\mathrm{a}^{\sharp} \mathrm{b}^{*}}$ & $30.64 \pm 2.27^{\mathrm{a}^{*} \mathrm{~b} \#}$ & $7.10 \pm 0.21^{\mathrm{a}^{*} \mathrm{~b}^{*}}$ & $5.01 \pm 0.30^{\mathrm{a}^{*} \mathrm{~b}^{*}}$ & $27.55 \pm 1.31^{\mathrm{a}^{*} \mathrm{~b}^{*}}$ \\
\hline
\end{tabular}

Activities of enzymes are expressed as: $50 \%$ of inhibition of epinephrine autoxidation $/ \mathrm{min}$ for SOD; $\mathrm{mM}$ of hydrogen peroxide decomposed/min/mg of protein for catalase; $\mathrm{mM}$ of glutathione oxidized/min/mg of protein for GPx; U/min $/ \mathrm{mg}$ of protein for GST; $\mu \mathrm{M}$ of DTNB-GSH conjugate formed/min/mg of protein for GR.

Results are expressed as mean \pm S.E.M [n=6]. One-way ANOVA followed by post hoc test LSD. The results were compared with ${ }^{\mathrm{a} C o n t r o l ~ r a t s, ~}{ }^{\mathrm{b}} \mathrm{Diabetic}$ rats,

cDiabetic rats treated with metformin. Values are statistically significant at ${ }^{\circledR} \mathrm{P}<0.05 ;{ }^{*} \mathrm{P}<0.01 ;{ }^{*} \mathrm{P}<0.001$. 
Table 10 Effect of S.potatorum seeds extract on the levels of Vitamin E, Vitamin C, Ceruloplasmin and reduced glutathione in plasma of control and experimental groups of rats.

\begin{tabular}{lcccc}
\hline Groups & Vitamin E & Vitamin C & Ceruloplasmin & GSH \\
\hline Control & $1.00 \pm 0.06$ & $1.53 \pm 0.080$ & $14.00 \pm 0.13$ & $38.81 \pm 2.48$ \\
Diabetic & $0.40 \pm 0.031^{\mathrm{a}^{*}}$ & $0.46 \pm 0.048^{\mathrm{a}^{*}}$ & $5.00 \pm 0.32^{\mathrm{a}^{*}}$ & $17.00 \pm 1.12 \mathrm{a}^{\mathrm{a}^{*}}$ \\
Diabetic + S.potatorum & $0.81 \pm 0.052^{\mathrm{ab}^{*} \mathrm{c}}$ & $0.94 \pm 0.073^{\mathrm{a}^{*} \mathrm{~b}^{*} \mathrm{c}}$ & $10.11 \pm 0.56^{\mathrm{a}^{*} \mathrm{~b}^{*}}$ & $27.41 \pm 1.911^{\mathrm{a}^{*} \mathrm{~b}^{*}}$ \\
Diabetic + metformin & $0.86 \pm 0.04^{\mathrm{a}^{*} \mathrm{~b}^{*}}$ & $1.00 \pm 0.043^{\mathrm{a}^{*} \mathrm{~b}^{*}}$ & $11.08 \pm 0.45^{\mathrm{a}^{*} \mathrm{~b}^{*}}$ & $29.33 \pm 1.28^{\mathrm{a}^{*} \mathrm{~b}^{*}}$ \\
\hline
\end{tabular}

Units are expressed as: $\mathrm{mg} / \mathrm{dl}$.

Results are expressed as mean \pm S.E.M [n=6]. One-way ANOVA followed by post hoc test LSD. The results were compared with ${ }^{\mathrm{a} C o n t r o l ~ r a t s, ~}{ }^{\mathrm{D}}$ Diabetic rats,

${ }^{c}$ Diabetic rats treated with metformin. Values are statistically significant at ${ }^{\circledR} \mathrm{P}<0.05 ;{ }^{*} \mathrm{P}<0.01 ;{ }^{*} \mathrm{P}<0.001$.

Table 11 Effect of S.potatorum seeds extract on the level of reduced glutathione in pancreas, liver and kidney tissues of control and experimental groups of rats.

\begin{tabular}{|c|c|c|c|}
\hline \multirow[b]{2}{*}{ Groups } & \multicolumn{3}{|c|}{ Reduced glutathione } \\
\hline & Pancreas & Liver & Kidney \\
\hline Control & $22.44 \pm 1.22$ & $48.10 \pm 2.67$ & $36.40 \pm 1.91$ \\
\hline Diabetic & $9.04 \pm 0.422^{a^{*}}$ & $23.41 \pm 1.19^{a^{*}}$ & $21.03 \pm 0.78^{\mathrm{a}^{*}}$ \\
\hline Diabetic + S.potatorum & $14.92 \pm 0.42^{\mathrm{a}^{*} \mathrm{~b}^{*} \mathrm{c}}$ & $38.30 \pm 2.70^{\mathrm{a} * \mathrm{~b}^{*} \mathrm{c}}$ & $28.10 \pm 1.58^{\mathrm{a}^{*} \mathrm{~b} \# \mathrm{c}}$ \\
\hline Diabetic + metformin & $17.00 \pm 0.99^{\mathrm{a}^{*} \mathrm{~b}^{*}}$ & $40.10 \pm 2.01^{\mathrm{a}^{*} \mathrm{~b}^{*}}$ & $30.27 \pm 1.18^{\mathrm{a}^{\mathrm{b}} \mathrm{b}^{*}}$ \\
\hline
\end{tabular}

Units are expressed as: $\mathrm{mg} / 100 \mathrm{~g}$ of wet tissue.

Results are expressed as mean \pm S.E.M [n=6]. One-way ANOVA followed by post hoc test LSD. The results were compared with a Control rats, ${ }^{b}$ Diabetic rats,

${ }^{\mathrm{c}}$ Diabetic rats treated with metformin. Values are statistically significant at ${ }^{\circledR} \mathrm{P}<0.05 ;{ }^{*} \mathrm{P}<0.01 ;{ }^{*} \mathrm{P}<0.001$.

values by the treatment of S.potatorum seeds extract as well as metformin to diabetic groups of rats (Tables 3,4,5 and 6) respectively.

Tables 7, 8 and 9 depict the activities of enzymatic antioxidants such as SOD, catalase, Gpx and GST in pancreatic, hepatic and renal tissues of control and experimental groups of rats. The diminished activities of the above enzymes in all the three tissues of the diabetic group of rats were improved after oral treatment with seeds extract. The observed decrease in the levels of plasma non-enzymatic antioxidants such as vitamin $\mathrm{C}$, vitamin $\mathrm{E}$ and ceruloplasmin (Table 10) and pancreatic, hepatic and renal GSH (Table 11) in the experimental diabetic group of rats were improved to the physiological range after treatment with seeds extract as well as metformin.

\section{DISCUSSION:}

The high fat diet fed and low dose Streptozotocin induced experimental type 2 diabetes in rats resembles most of the clinical features of human type 2 diabetes and hence it was chosen as the animal model to evaluate the anti diabetic as well as antioxidant properties of the S.potatorum seeds extract. ${ }^{12}$ The acute and chronic toxicity studies revealed the non toxic nature of the seeds extract up to $2000 \mathrm{mg}$ $/ \mathrm{kg} /$ body weight which was in line with previous reports. ${ }^{25}$ The optimal dose fixed as $500 \mathrm{mg} / \mathrm{kg} /$ bw/rat/day for 30 days was higher than the reports available in the literature which in turn may be due to the difference in the selection of solvents for the extraction of active principles in the seeds extract. The data obtained through qualitative phytochemical screening, the phenolic and flavonoids contents in the seeds extract are comparable with the earlier reports of Mallikharjuna et al., (2007). ${ }^{26}$

Blood glucose is a reliable biochemical index for early diagnosis and prognosis of diabetes mellitus. During diabetes, the blood glucose levels are consistently increased which results from reduced glucose utilization by various tissues, which is the typical condition of insulinopenic. HbAlc is defined as a function of glucose glycation at one or more sites on the hemoglobin molecule and the International Diabetes Federation recommended the diagnosis of diabetes mellitus by assessing HbA1c levels. HbA1c levels represent average glycemia over the entire 120-day lifespan of the red blood cell. Extensive studies on HbAlc bring out the magnitude of $\mathrm{HbA} 1 \mathrm{c}$ as a non-manipulatable and reliable biochemical parameter is appraising metabolic control as compared to one-point blood glucose estimation. ${ }^{27}$

The observed increase in insulin level along with decreased levels of fasting blood glucose and glycosylated hemoglobulin in diabetic rats treated with seeds extract evidencing that the seeds extract possess insulin stimulatory and/or insulin mimetic properties. The absence of sugar in the urine samples of $S$. potatorum seeds extract treated rats evidenced the maintenance of normoglycemia and 
its renoprotective effect. Several reports are available in the literature regarding the non toxic nature as well as the hypoglycemic efficacy of the seeds extract. $^{25}$

Diabetogen induced experimental diabetes in animal models indicates several alterations of amino acid metabolism, which may be attributed to increased muscle proteolysis, reduced protein synthesis, an energy-dependent process in the liver and stimulated hepatic gluconeogenesis utilizing gluconeogenic amino acids. This readily accounts for the observed decrease in the total protein content in diabetic rats. Oral administration of seeds extract to diabetic rats significantly controls proteolysis caused by insulin deficiency and improves total protein levels to near normalcy indicating the beneficial and pharmacological properties of seeds extract.

Further, the supraphysiological concentration of glucose in the diabetic state causes severe derangement in protein metabolism which results in the development of negative nitrogen balance. This, in turn, increases the levels of both blood urea and serum creatinine which acts as a diagnostic marker for assessing renal impairment and drug-induced toxicity. The observed alteration in the levels of blood urea and serum creatinine in the group of diabetic rats reverted to physiological values by treatment with seeds extract, indicating that the impairment of renal functions occurred in the diabetic rats were significantly improved by the oral administration of seeds extract. Likewise, the increased levels of serum uric acid observed in diabetic rats were restored to near normal range by the oral administration of seeds extract indicating the free radical scavenging activity of seeds extract.

Experimental and clinical reports evidenced the role of chronic hyperglycemia induced oxidative stress in the etiology of diabetes mellitus and its secondary complications. ${ }^{2}$ Hence the antioxidant efficacy of the seeds extract was evaluated by analyzing the extent of oxidative stress markers such as lipidperoxides, hydroperoxides and protein carbonyls in the plasma, pancreas, hepatic and renal tissues. The status of enzymatic and non enzymatic antioxidants in the diabetic and the experimental groups of rats was determined. The increased levels of oxidative stress markers were brought back to near control values after treatment with seeds extract. Likewise, the decreased levels of enzymatic and non enzymatic antioxidants were elevated to near normalcy after treatment with the seeds extract. Thus the data obtained clearly evidenced the antioxidant properties of the seeds extract. The observed decrease in the levels of fasting blood glucose, glycosylated hemoglobin, urea, uric acid, creatinine and oxidative stress markers such as lipid peroxides, hydro peroxides and protein carbonyls along with a concomitant increase in the levels of both enzymatic and non enzymatic antioxidants in the diabetic rats treated with the seeds extract revealed the significant antidiabetic and antioxidant properties of the S.potatorum seeds which in turn may be due to the presence of pharmacologically important phytochemicals present in the seeds extract. Several reports are available in the literature to show that the S.potatorum seeds extract contains pharmacologically active phyto ingredients such as diaboline, strychnine, brucine, struxine, oleanolic acid, loganin, vanprukoside, strychnoside, flavonoids and steroids. ${ }^{28}$ The observed antidiabetic and antioxidant properties of S.potatorum seeds are in accordance with the earlier reports of Sanmugapriya and Venkataraman (2006) and Bhushan et al., (2013) respectively. ${ }^{29,25}$

In conclusion, the data obtained revealed the presence of pharmacologically important phytochemicals in the seeds extract. The results of the present study evidenced the antidiabetic and antioxidant properties of the Strychnos potatorum seeds. The observed hypoglycemic actions of the seeds extract may be due to its antioxidant properties. Above all, the study provides a scientific rationale for the use of S.potatorum seeds in traditional medicine.

\section{CONFLICT OF INTEREST STATEMENT}

The authors declare that there is no conflict of interest.

\section{REFERENCES:}

1. Shaw JE, Sicree RA and Zimmet PZ. Global estimates of the prevalence of diabetes for 2010 and 2030. Diabetes Research and Clinical Practice. 2010;87(1):4-14

2. Fatmah AM, Siti BB, Zariyantey AH, Nasar A, Jamaludin M. The Role of Oxidative Stress and Antioxidants in Diabetic Complications. Sultan Qaboos Univ Med J. 2012; 12(1): 5-18.

3. Ergul BK. The importance of antioxidants which play the role in cellular response against oxidative/nitrosative stress: current state. Nutr J. 2016; 15(71):1-22.

4. Rena G, Hardie DG, Pearson ER. The mechanisms of action of metformin. Diabetologia. 2017; 60: 1577-1585.

5. Sharmila C and Subramanian SP. Studies on the Defluoridization Competency of a Mixture of Raw Vermiculite and Strychnos Potatorum linn. Seeds. Der Pharma Chemica. 2019; 11(6): 1-6.

6. Biswas A, Kanti GT, Ghosh, Joydip PA, Kallol B, Halder D. Hypoglycemic Effect of Strychnos Potatorum Linn were Compared with Glipizide on Male Diabetic Rats. Indian Medical Gazette. 2014; 297-303.

7. Harborne JB. Phytochemical methods, Chapman and Hall Int., New York,1998; Third Edition.

8. Singleton VL, Orthofer R, Lamuela-Raventos RM , Analysis of total phenols and other oxidation substrates and antioxidants by means of Folin-Ciocalteu reagent, Methods Enzymol. 1999; 299:152-78. 
9. Quettier-Deleu C, Gressier B, Vasseur J, Dine T, Brunet C, Luyckx M, et al,. Phenolic compounds and antioxidant activities of buckwheat (Fagopyrum esculentum Moench) hulls and flour. J Ethnopharmacol. 2000; 72(1-2):35-42.

10. Miller GL, Use of dinitrosalicylic acid reagent for determination of reducing sugar, Analytical Chemistry. 1959; 31(3):426-428.

11. Lowry $\mathrm{OH}$, Rosebrough NJ, Farr AL and Randall RJ. Protein measurement with the Folin phenol reagent. J Biol Chem. 1951; 193:265-275.

12. Suman RK, Mohanty IR, Borde MK, Maheshwari U, Deshmukh YA. Development of an experimental model of diabetes co-existing with metabolic syndrome in rats. Advances in Pharmacological Sciences. 2016; 1-11.

13. Rakieten N, Rakieten ML, Nadkarni MV. Studies on the diabetogenic action of streptozotocin (NSC-37917). Cancer Chemother Rep. 1963; 29: 91-98.

14. Yagi KA. Simple fluorometric assay for lipoperoxide in blood plasma. Biochem Med.1976; 15(2):212-6.

15. Ohkawa H, Ohishi N, Yagi K. Assay for lipid peroxides in animal tissues by thiobarbituric acid reaction. Anal Biochem. 1979; 95(2):351-8.

16. Jiang ZY, Hunt JV, Wolff SP. Ferrous ion oxidation in the presence of xylenol orange for detection of lipid hydroperoxide in low density lipoprotein. Anal Biochem. 1992; 202(2):384-9.

17. Misra HP and Fridovich I. The role of superoxide anion in the autoxidation of epinephrine and a simple assay for superoxide dismutase. J Biol Chem. 1972; 247(10):3170-5.

18. Takahara S, Hamilton HB, Neel JV, Kobara TY, Ogura Y, Nishimura ET. Hypocatalasemia: a new genetic carrier state. J Clin Invest. 1960; 39:610-9.

19. Rotruck JT, Pope AL, Ganther HE, Swanson AB, Hafeman DG, Hoekstra WG. Selenium: biochemical role as a component of glutathione peroxidase. Science. 1973; 179(4073):588-90

20. Habig WH, Pabst MJ, Jakoby WB. Glutathione S-transferases the first enzymatic step in mercapturic acid formation. J Biol Chem. 1974; 249(22):7130-9.

21. Omaye ST, Turnbull JD, Sauberlich HE. Selected methods for the determination of ascorbic acid in animal cells, tissues, and fluids. Methods Enzymol. 1979; 62:3-11.
22. Desai ID. Vitamin E analysis methods for animal tissues. Methods Enzymol. 1984; 105:138-47.

23. Ravin HA. An improved colorimetric enzymatic assay of ceruloplasmin. J Lab Clin Med. 1961; 58:161-8.

24. Sedlak J and Lindsay RH. Estimation of total, protein-bound, and nonprotein sulfhydryl groups in tissue with Ellman's reagent. Analytical Biochemistry. 1968;25: 192-205

25. Bhushan MS, Amita V, Madhavan V. Preclinical valuation of anti-hyperglycemic and antioxidant action of Nirmali (Strychnos potatorum) seeds in streptozotocin-nicotinamide-induced diabetic Wistar rats: A histopathological investigation. Biomarkers and Genomic medicine. 2013; 5:157-163.

26. Mallikharjuna PB, Rajanna LN, Seetharam YN, et al. Phytochemical studies of Strychnos potatorum L.f a medicinal plant. e-J Chem. 2007;4:510-518.

27. Shariq I, Sherwani, Haseeb KA, Aishah E, Afshan M, Meena, Sakharkar K. Significance of HbAlc Test in Diagnosis and Prognosis of Diabetic Patients. Biomark Insights. 2016; 11: 95-104

28. Singh AK, Dhar DN. Studies on the chemical constituents of the seeds of Strychnos Potatorum L. part I. Planta Med. 1977; 32(8):362-367.

29. Sanmugapriya E \& Venkataraman S. Studies on hepatoprotective and antioxidant actions of Strychnos potatorumLinn. seeds on CCl4-induced acute hepaticinjury in experimental rats. Journal of Ethnopharmacology. 2006; 105:154-160.

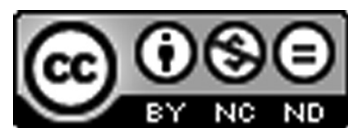

This work is licensed under a Creative Commons Attribution-Non Commercial-No Derivatives 4.0 International License. To view a copy of this license, visit http://creativecommons.org/licenses/by-nc-nd/4.0/ 